University of Warwick institutional repository: http://go.warwick.ac.uk/wrap This paper is made available online in accordance with publisher policies. Please scroll down to view the document itself. Please refer to the repository record for this item and our policy information available from the repository home page for further information.

To see the final version of this paper please visit the publisher's website. Access to the published version may require a subscription.

Author(s): Peter Marshall

Article Title: Mumpsimus and Sumpsimus: The Intellectual Origins of a Henrician Bon Mot

Year of publication: 2001

Link to published version:

http://dx.doi.org/doi:10.1017/S0022046901005978

Publisher statement: None 
Notes And Doguments

\title{
Mumpsimus and Sumpsimus: The Intellectual Origins of a Henrician Bon Mot
}

\author{
by PETER MARSHALL
}

$\mathrm{H}$

enry viII's appearance before the assembled houses of parliament on Christmas Eve I 545 was perhaps his finest hour. In what has been called a 'pioneer royal Christmas broadcast', the king delivered an impassioned and eloquent speech lamenting the religious divisions that afflicted his kingdom, and urging his subjects towards unity and charity. ${ }^{1}$ According to William Petre, the king himself wept as he recounted how 'charity between man and man is so refrigerate', and few of his audience could restrain themselves from doing likewise. ${ }^{2}$ Another eye-witness, the chronicler Edward Hall, wrote down the speech 'worde for worde, as near as I was able to report it'. This account gives details of how Henry illustrated the breakdown of fraternal love among his people: 'the one calleth the other Hereticke and Anabaptist, and he calleth hym again, Papist, Yypocrite and Pharisey'; rival preachers inveighed against each other 'without charity or discrecion'. To the king's mind, the blame for this deserved to be apportioned to all sides, and, to reinforce the point, Henry brought forward one of the more curious metaphors of contemporary religious discourse: 'some be to styff in their old Mumpsimus, other be to busy and curious in their newe Sumpsimus'. ${ }^{3}$

I wish to thank Professor Diarmaid MacCulloch and Mr Alec Ryrie for their helpful comments on a draft of this note.

1 The phrase is Diarmaid MacCulloch's: Thomas Cranmer: a life, New Haven-London I $996,34^{8}$.

${ }_{2}^{2}$ PRO, SP I / 2 I 2, fos I I OV-I Ir (Letters and papers, foreign and domestic, of the reign of Henry VIII, ed. J. S. Brewer, J. Gairdner and R. H. Brodie, London I862-I9io [hereinafter cited as $L P], \mathrm{xx} / 2$, I030).

${ }^{3}$ E. Hall, Hall's Chronicle, ed. H. Ellis, London i809, 864-5. The charge of religious name-calling was hardly new in I545. In an earlier exhortation to unity and charity, 
Recent historians of the reign have understandably devoted considerable attention to his speech, arguably the most famous of all Henry viII's public pronouncements, and most have quoted the mumpsimus-sumpsimus idiom, with varying degrees of wry amusement. ${ }^{4}$ Yet there has been little attempt to explain why the king should use precisely these words to epitomise the polarisation of religious positions in the early I 540 s. $^{5}$ It is not always apparent from modern accounts that the terms 'mumpsimus' and 'sumpsimus' did not represent the king's own assay at faux-bucolic neologism, but were an established (though not long-established) literary trope. In the following short discussion, I hope to demonstrate how an investigation of the derivation and precedents of the phraseology employed by Henry in his Christmas speech can throw some revealing light on the processes by which religious typologies were constructed and utilised in the course of the Henrician Reformation, as well as providing some points of orientation in that most formidable of terrae incognitae, the mind of Henry vin himself. ${ }^{6}$

Credit for introducing mumpsimus and sumpsimus to the language is given by the Oxford English dictionary to the humanist and diplomat Richard Pace, but in fact the origins of the phrase can be traced further back, to the lodestar of the early sixteenth-century humanist movement, Desiderius Erasmus. In a letter of August I 5 I 6 to an English correspondent, Henry Bullock, Erasmus railed against the opponents of his recent edition of the New Testament, specifically those who were arguing that no textual changes to Scripture were permissible unless it were on the authority of a general council. This seemed to Erasmus wilfully block-headed; the corruption in some passages were too obvious to be overlooked, and by way of analogy he brought in a personal reminiscence. A printer in Paris,

Thomas Starkey had lamented the fact that 'eche one in hart iugeth other to be eyther pharisee or heretyke, papist or schismatike': An exhortation to the people instructynge them to unitie and obedience, London ? I536, fo. $27 \mathrm{v}$.

${ }^{4}$ J. J. Scarisbrick, Henry VIII, London i 968, 470-I ; S. E. Lehmberg, The later parliaments of Henry VIII 1536-1547, Cambridge 1977, 229-3 ; S. Brigden, London and the Reformation, Oxford I989, 378; G. R. Elton, England under the Tudors, 3rd edn, London i99I, 200; C. Haigh, English reformations : religion, politics, and society under the Tudors, Oxford I 993, I64; R. Rex, Henry VIII and the English Reformation, Basingstoke I993, I72; MacCulloch,

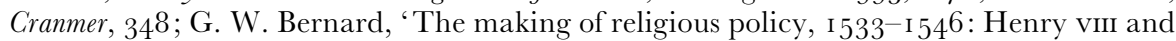
the search for the middle way', Historical Fournal xli (1998), 348.

5 The exception here is Lehmberg, Later parliaments, 23 I, which notes that the phrase was derived from a I 5 I 7 treatise by Richard Pace. As I shall show, this does not give the complete picture.

${ }^{6}$ For two recent stimulating, though contrasting, attempts to locate Henry's religious centre of gravity see Bernard, 'The making of religious policy'; D. MacCulloch, 'Henry viII and the reform of the Church', in D. MacCulloch (ed.), The reign of Henry VIII: politics, policy and piety, Basingstoke i 995, I 59-80. 
possessed of a mere smattering of learning, had confessed to him that twenty years earlier his press had produced service books and books of hours according to the use of Trier, which were subsequently found to have a great many discrepancies and errors. Of course, Erasmus noted, the printer corrected them all for subsequent editions, just as the leaders of the Church should now be willing to allow necessary corrections to the far more important text of holy writ itself. If they opposed this, they would resemble 'the mass-priest who refused to change the word mumpsimus which he had used for twenty years, when someone told him that sumpsimus was what he ought to say'. ${ }^{7}$ The context for the malapropism is the postcommunio prayer in the canon of the mass, where 'sumpsimus' (the first-person plural perfect indicative of 'sumere', to take up) appears in numerous variant settings. ${ }^{8}$ Erasmus does not claim directly that this priest had been using one of the defective Trevisan missals, though the implication is that some such corrupted text (a simile for the Vulgate) must have come into his hands. Whether such a priest ever really existed must remain questionable. The letter was included in the edition of Erasmus' letters published at Louvain in I5 6, and thus came to the attention of the English humanist scholar, royal secretary and diplomat, Richard Pace. ${ }^{9}$ Pace was clearly taken with the anecdote. In a letter to Erasmus from Constance of 5 August I 5 I 7 , he reported that a collection of Erasmus' letters had come into his hands, and wholeheartedly joined with him in excoriating critics of the New Testament: 'They ought to be satisfied by your story of our mass-priest and his mumpsimus for sumpsimus. ${ }^{10}$ Moreover, he appropriated the exemplum for a work of his own appearing from the Basle presses later that same year, De fructu qui ex doctrina percipitur, an educational treatise, extolling the different branches of learning and the benefits they variously confer. ${ }^{11}$ Here the ignorant cleric

\footnotetext{
7 Opus epistolarum De. Erasmi Roterodami, ed. P. S. Allen, H. H. Allen and H. W. Garrod, Oxford I 906-58, ii. 322-3; The correspondence of Erasmus: letters 446 to 593: ${ }_{5}$ I 6 to I $_{5}$ I7, ed. and trans. R. A. B. Mynors and D. F. S. Thompson, Toronto 1977, 43-6, where it is pointed out at p. $46 \mathrm{n}$. that no record can be found of breviaries, missals or primers after the use of Trier being printed at Paris in this period. Troyes is suggested as an alternative.

8 The Sarum missal, ed. J. W. Legg, Oxford I 9 i 6, I94, 234, 237, 284, 296, 320, 326, 333, $338,343,364,394$.

9 Pace had been part of the community of young English scholars in Padua at the turn of the sixteenth century, and had been known to Erasmus since about I 508. On his career see J. Wegg, Richard Pace: a Tudor diplomat, London i 932; R. Pace, De fructu qui ex doctrina percipitur, ed. F. Manley and R. S. Sylvester, New York I967, introduction; J. Woolfson, Padua and the Tudors: English students in Italy, 1485-1603, Cambridge I998. The most substantial recent work is C. M. Curtis, 'Richard Pace: pedagogy, counsel and satire', unpubl. PhD diss. Cambridge I997.

${ }_{10}$ Opus epistolarum Erasmi, iii. 40; The correspondence of Erasmus: letters 594 to 841 : 1517 to I5I8, ed. and trans. R. A. B. Mynors and D. F. S. Thompson, Toronto i979, 58-9.

${ }^{11}$ De fructu qui ex doctrina percipitur, Basle I 5 I 7 . The references which follow are to the modern edition by F. Manley and R. S. Sylvester, cited in n. 9 .
} 
has become 'a certain boorish English priest' ('quidam indoctus sacrificius Anglicus'), who has a part to play in a debate between Rhetoric and Grammar over the importance of teaching the proper names and forms of letters. In their discussion, ' $\mathrm{S}$ ' is found to be the most unfortunate of letters, as the afore-mentioned cleric had driven her away from her own property for thirty years, being 'not ashamed at having read mumpsimus instead of sumpsimus for that long a time. And when a learned man advised him to correct the mistake, he replied that he didn't want to change his old mumpsimus for some new sumpsimus'. ${ }^{12}$ Clearly, Pace found the expression a useful all-purpose tool for the indictment of obscurantism, for he used it in another place in the same treatise to lambast certain medical doctors. These, ignoring the advice of Nicolas Leonicensus, Professor of Medicine at Ferrara, had failed to learn Greek properly and thus prescribed the snake-bite antidote theriaca without knowing how to prepare it properly: 'they preferred to use their old mumpsimus rather than Leonicensus' - or rather, Truth's - sumpsimus'. ${ }^{13}$ The suitability of the phrase for characterising opponents of classical learning struck a chord with other English humanists. In his Boke named the gouernor (I53 I), Sir Thomas Elyot devoted a chapter to 'Magnanimitie... a vertue much commendable and expedient in a governor'. He recognised, however, that the word 'beinge yet straunge, as late borowed out of the latyne, shall not content all men, and specially them whome nothing contenteth out of their accustomed Mumpsimus', proposing 'good courage' as a more familiar synonym. ${ }^{14}$

In short, 'mumpsimus' was part of the currency of humanist wordplay, a pointedly referential Latinate joke, which may have appealed particularly in the English setting because of its suggestion of mummering or mumming, terms which meant both muttering or mumbling, and the disguising and play-acting associated with mummers' plays. ${ }^{15}$ To humanists, it was a versatile weapon of ridicule, though one which had been forged from their characteristic disdain for the ignorant mass of the parish clergy. Impatience with clerical shortcomings was de rigueur among the circle of Erasmus' acquaintance in early sixteenth-century England, with figures like Thomas More and John Colet arguing that what the Church needed was fewer priests and better ones. ${ }^{16}$ In an ordination sermon of around i5 Io, Colet's friend, the chancellor of York Minister,

12 Pace, De fructu, I 02-3. 13 Ibid. 64-5.

14 T. Elyot, The boke named the gouvernor, ed. H. Croft, London I 88o, ii. 288-9.

15 Oxford English dictionary, 2nd edn, Oxford ig9 I, s.v. 'mum', 'mummer'; cf. John Skelton's poem, Collyn Clout, where the ignorance of the clergy is mocked in these terms: 'And as for theyr connynge,/A glommynge and a mommynge': The complete English poems, ed. J. Scattergood, London i983, 248.

16 P. Marshall, The Catholic priesthood and the English Reformation, Oxford I 994, 56, 59; J. R. Lander, Government and community: England, I450-I509, London I980, I29-30. 
William Melton spoke of that 'crop of oafish and boorish priests' liable to 'throw aside their books in contempt' at the slightest temptation. ${ }^{17}$ That priests should be no more than barely competent (if that) in the liturgy was a particular source of humanist sarcasm. In his fictive Dialogue between Pole and Lupset, Thomas Starkey bewailed the scandal whereby unlearned curates were placed in benefices who very often could do no more 'but pattur up theyr matyne and mas, mumblyng up a certayn nombur of wordys no thyng understonde'.${ }^{18}$ In a letter to Starkey (then in Padua) from Valladolid in July I 535, the scholar-diplomat John Mason invoked the story of an 'ignorant preist of my contrey' who was clearly first cousin to the champion of mumpsimus. This cleric "wolde not suffer the name of Satanas in the Masbook, butt strake itt owte and putt God in the place of itt, and so he made "abrenuncio Deo et omnibus operibus ejus". ${ }^{19}$ Within the world of humanist scholarship then, the mumpsimus-sumpsimus motif can be seen to have had a dual function, serving to lampoon both the ignorant parish clergy, and the more highly-placed and formallyeducated opponents of humanist learning. The particular potency of the concept derived from its utility for conflating the latter with the former.

It was these transferable properties of the mumpsimus metaphor which help explain its attraction for the first generation of English evangelical reformers. Like the humanists, early reformers had nothing but contempt for the 'Sir John Lack-Latins' among the parish clergy, mumbling their matins without understanding. ${ }^{20}$ But they were under no illusions that the real obstacles to the implementation of the gospel were their 'papistical' enemies in the episcopate and among the higher clergy. It is in this context that we find the first deployment of the mumpsimus theme by an English evangelical, in William Tyndale's Practice of prelates (I530), a work which, against the trend of English reformist opinion, opposed Henry viII's divorce from Catherine of Aragon. In Tyndale's account, Cardinal Wolsey, having planted the idea in Henry's mind that Catherine was not his true wife, used as a pretext the condemnation of the evangelicals Arthur and Bilney to call together all his doctors and chancellors 'to seek subtle arguments and riddles to prove his divorcement'. These ecclesiastics, affirmed Tyndale, were 'all lawyers, and other doctors, mumpsimuses of divinity'. ${ }^{21}$ This was a direct iteration of the Erasmian

17 W. Melton, Sermo exhortatorius cancelarii eboracensis, London c. I5Io, sig. Aiiiir, translated extract in A. G. Dickens and D. Carr (eds), The Reformation in England to the accession of Elizabeth I, London I967, I5-I6.

18 T. Starkey, A dialogue between Pole and Lupset, ed. T. F. Mayer (Camden $4^{\text {th }}$ ser. xxxvii, I989), 88.

${ }^{19}$ H. Ellis (ed.), Original letters illustrative of English history, 2nd ser., London I827, ii. 58-9. $\quad 20$ On this theme see Marshall, Catholic priesthood, 96-8.

${ }_{21} \mathrm{~W}$. Tyndale, Expositions and notes on sundry portions of the holy Scriptures together with the practice of prelates, ed. H. Walter (Parker Society, I849), 320. 
critique of 'scholarly ignorance', albeit in a much more overtly doctrinal context. The mumpsimus here metonymically stood for the doctors themselves, and was intended to signify not so much a lumpish attachment to outdated modes of textual criticism, but rather a shorthand code for opposition to the biblicist and solifidian agenda Tyndale was seeking to promote. In this sense, mumpsimus was to prove a potent weapon in the rhetorical armoury of English Protestantism, functioning in a manner similar to the polemical expression 'new learning', which, as Richard Rex has shown, was widely employed by religious conservatives in Henrician England as a loose (and therefore adaptable and effective) synonym for heresy. ${ }^{22}$ Indeed, an important aspect of the appeal of mumpsimus was that it so pithily subverted the polemical agenda encapsulated in the sarcastic sobriquet 'new learning'. If the Catholics' teaching could be represented as 'mumpsimus', then it was they rather than the evangelicals who ought to be associated with 'novelty', and with demonstrably corrupt deviation from true apostolic doctrine.

Some further examples will help to establish these points. In March I535 Thomas Skypwyth and Gregory Waren wrote to Cromwell to complain about the clergy in the liberty of St Albans, whose misdemeanours included making treasonous utterances in confession, condemning the works of Luther, Melanchthon, Tracy, Tyndale and Frith, and denouncing as heretics any who loved the Word of God, or whom they suspected of the 'new learning'. It was sadly reported that there were no priests in the area 'that doth manyfest the full trwght in ther prechyng, but rather smellyth of ther olde mumsymus', with the exception of the archdeacon, the curate and a monk of St Albans Abbey. ${ }^{23}$ Cromwell was hearing about mumpsimus from other correspondents in I 535, among them another solitary evangelical monk, John Placett of Winchcombe. Placett wrote offering to take up his pen against 'mony wolde bokys and ragyde pawmphylions de purgatorio... whych hath cawsyde sum men to be yn there olde mumsimus' ${ }^{24}$ From an evangelical perspective, the very epitome of the type in the summer of 1535 were the inmates of the London charterhouse. In the aftermath of the execution of Prior John Houghton, a client of Cromwell's, John Whalley, had been imposed as procurator with a brief to reduce the remaining Carthusians to conformity and obedience. While formulating grandiose plans to subject them to a barrage of exhortations from all the leading bishops, Whalley complained of their utter intractability in a letter to Cromwell: 'no question of it, they be excedingly supersticious, ceremonius and phrasaicall, and wondesly addicte to theire olde Mumpsimus'. ${ }^{25}$

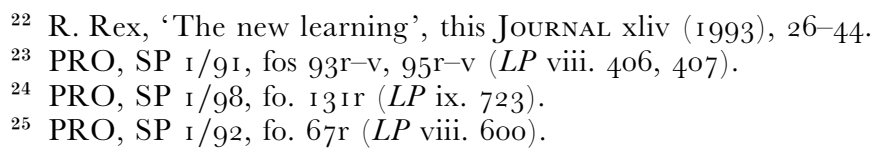


The phrase was used in almost exactly the same sense in May I 54 I by no less a figure than Archbishop Thomas Cranmer, as tensions erupted between conservatives and radicals among the new prebendaries of his cathedral church of Canterbury. ${ }^{26}$ At Faversham, Cranmer confronted two of the most implacable opponents of further reform, Arthur St Leger and Richard Parkhurst. The archbishop accused them of being knit together in a bond which he was determined to break. His earlier good judgement of them had proved misplaced, for 'ye wyll not leve your olde mumsemundes; but I will make you to leave them or else I will make ye to repent it'. According to his own account, St Leger made a calm and dignified reply: 'I trust we use no mumsemundes but these that be consonant to the laws of God and owr Prynce. ${ }^{27}$ The protean qualities of the term are particularly evident in these last examples. No more than the monks of the charterhouse could either prebendary be plausibly represented as an ignorant rural curate: St Leger was a former prior of Leeds, and brother of the powerful local landowner, Sir Anthony St Leger; Parkhurst was a former secretary of Archbishop Warham. ${ }^{28}$

Yet it would seem that while Cranmer was invoking mumpsimus to lambast the conservative clergy of Kent, the term remained sufficiently capacious not to become simply an emblematic party label, or the sole property of an evangelical faction. In April ${ }_{5} 538$ it turns up in a rather unexpected place, a somewhat ingratiating letter from the archconservative nobleman, Thomas Howard, duke of Norfolk to his governmental colleague (and arch-rival) Thomas Cromwell. With reference to some unspecified 'pronostications' that Cromwell had apprised him of, Norfolk commented: 'I thinke almightie god doth entende no longer to wynke, but to loke brodewaking, aswell on those that do determine themselffes to followe his comawndementes as on thothers acordinge to their desertes, that be bent to followe their olde mumpsimus, and superstitions.' He thought it likely that God would shortly visit punishment upon the bishop of Rome, his 'ungratiouse cardinalles', and all who support their 'damnable procedinges'. ${ }^{29}$ This can be read as an example of more self-consciously 'Henrician' rhetoric, seeking to associate 'superstition' and 'mumpsimus' directly with Roman allegiance, rather than with adherence to traditional sacramental theology. ${ }^{30}$

In the years after I 545, mumpsimus seems more securely located in the polemical vocabulary of Protestantism, where it was to enjoy an extremely

${ }^{26}$ These were to lead to attempts to unseat Cranmer in the so-called 'Prebendaries' Plot', on which see M. L. Zell, 'The Prebendaries Plot of I543: a reconsideration', this Journal xxvii (I976), 24I-53; MacGulloch, Cranmer, 297-322.

${ }^{27} L P$ xviii/2, 546, p. 378. See also ibid. pp. 322, 349 .

28 MacCulloch, Cranmer, 285, 299. 29 PRO, SP I/ I 3 I, io8r (LP xiii/ I, 784).

30 I explore some of the contours of this rhetorical strategy in 'The rood of Boxley, the blood of Hailes, and the defence of the Henrician Church', this Journal xlvi (I995), $689-96$. 
long shelf-life. ${ }^{31}$ In a sermon preached on the first Sunday in Advent in I552, Hugh Latimer characterised anyone sticking doggedly to the practice of fasting on Friday as determined to 'abide by his old Mumpsimus'. He returned to the image in a sermon on Sexagesima Sunday early the next year, indicting those who bore the name of Christians while being unable to abide the name of the Gospel: 'some be so obstinate in their old mumpsimus, that they cannot abide the true doctrine of God'. ${ }^{32}$ In his stirring autobiographical narrative of his travails in Mary's reign, the gospeller, Edward Underhill, described his interrogation before the Council in August I553 for composing a ballad against papists. Challenged by Sir John Gage as to what he meant by the term 'papist', Underhill archly retorted 'I thynke yff yow loke amonge the pristes in Pooles, ye shall fynde some old mumsymussis ther.' Gage was not amused: 'Mumsymussis, knave, (sayde he,) mumsymussis? Thou art an herytike. ${ }^{33}$

By the mid-i 550s, to dispense accusations of mumpsimus was to declare oneself a Protestant. As we have seen, however, the history of the phrase over the preceding four decades reveals a rather complex pedigree. Henry's version of I 545 - with its direct juxtaposition of 'mumpsimus' and 'sumpsimus' - might suggest a familiarity with Pace's text, but in variant forms the phrase was clearly current in circles close to the king himself. The foregoing brief examination of its diffusion after I5I6 suggests that Henry's utilisation of the motif on this most public of occasions cannot be used unproblematically as evidence that he was consciously steering a 'middle way' in religious matters. ${ }^{34}$ As informed contemporaries would have recognised, the king's bon mot was not quite so even-handed as it would first appear: sumpsimus is, at worst, pedantry, while mumpsimus is just plain wrong. As a pejorative label, 'sumpsimus' does not seem to have featured at all in anti-evangelical discourse of the I 530 a and I 540s. Yet in so far as linguistic meaning is the sum of linguistic usage, a deconstruction of the terms in which Henry framed his famous appeal for unity reveals a complex layering of strands and sources. What the king was invoking appears to represent the rhetoric of reformist Christian humanism, decisively appropriated into more overtly evangelical discourses, though still to an extent countenanced by the

${ }^{31}$ In the aftermath of the 'Popish Plot', for example, Robert Bolron described the Jesuits as the most zealous for the propagation of popery 'in their old Mumpsimus way': The narrative of Robert Bolron of Shippon-Hall, Gent. concerning the late horrid popish plot, London I680, 9 .

${ }^{32}$ H. Latimer, Sermons and remains, ed. G. E. Corrie (Parker Society, I845), I 7, 2 I I.

${ }_{33}$ Narratives of the days of the Reformation, ed. J. G. Nichols (Camden o.s. lxxvii, I 859), I 4 I.

${ }^{34}$ Bernard, 'The making of religious policy', 348, cites the passage as a final piece of evidence for Henry's 'middle way'. 
anticlerical and antipapal attitudes of conservative lay elites. It would perhaps be difficult to find a more perfect encapsulation of the idiosyncratic religious outlook of Henry viII, and of the complexities and ambiguities of the reforming processes he initiated; processes which, in I 545, he was trying, and failing, to bring under control. 